\title{
NAQLI AND AQLI ELEMENTS IN THE TEACHING AND LEARNING OF CHEMISTRY COURSE: A SURVEY ON TAMHIDI CENTRE, UNIVERSITI SAINS ISLAM MALAYSIA
}

\author{
Mohamed Akhiruddin Ibrahim ${ }^{1 *}$, Siti Rubaini Mat ${ }^{2}$, Latipah Mohd Noor ${ }^{2}$ and Afif \\ Arifin $^{2}$ \\ ${ }^{1}$ Dr., Senior Lecturer, Faculty of Quranic and Sunnah Studies, Universiti Sains Islam Malaysia, \\ MALAYSIA. akhiruddin@usim.edu.my \\ ${ }^{2}$ Teacher, Tamhidi Centre, Universiti Sains Islam Malaysia, MALAYSIA. \\ ${ }^{*}$ Corresponding author
}

\begin{abstract}
The process of teaching and learning containing both elements of Naqli and Aqli is very important to create a generation that develops from the diversity of knowledge which does not separate between religious and modern science knowledge. It is in accordance to the philosophy, vision and mission of Universiti Sains Islam Malaysia (USIM), the use of both Naqli and Aqli knowledges have been applied in chemistry course. Thus, this study is aimed to discover the students' perception towards the integration of Naqli and Aqli in the teaching and learning of chemistry course in Tamhidi Centre, USIM. To achieve the objective of this study, data were collected using quantitative method through questionnaires from 106 of Tamhidi students consisting of the groups from Medicine, Dentistry and Science and Technology. Responses from those students has provided with positive insights as they are exposed to knowledge of the science of chemistry mentioned in al-Quran. The findings of this study revealed that every item in the questionnaire has been given a good result with mean score exceeds four out of five-point Likert scale. Majority of students agreed that they were able to relate the concept of chemistry with revelation knowledge through the integration of Naqli and Aqli in teaching and learning. It is also found that there is a need to train the teachers regarding teaching methods in delivering Naqli and Aqli knowledge for better understanding among students. This is because the success of integrating Naqli and Aqli knowledge depends on how far the knowledge is mastered by the teachers. Further studies can be conducted to identify the effectiveness of Naqli and Aqli's approach among students in modern science subjects.
\end{abstract}

Keywords: Naqli, Aqli, Chemistry, Sciences 


\section{INTRODUCTION}

In the era of information revolution and globalization which speed up modernization, education faces the challenge of generating a balanced and holistic human capital from physical, emotional, spiritual and intellectual aspects. The objective of education stated in National Philosophy of Education is that education in Malaysia is an on-going effort towards further developing the potential of individuals in a holistic and integrated manner, so as to produce individuals who are intellectually, spiritually, emotionally and physically balanced and harmonious, based on a firm belief in and devotion to God. As a result, those individuals will contribute in creating a civilized society and encourage the development of the country (Shafeeq \& Rosy, 2014 pp. 163-164). Based on this, it shows that education is aimed to educate individuals for selfdevelopment in every aspect. The individual needs to be a knowledgeable, responsible and ethical in order to serve the community and nation.

However, today's dualism education system is unable to develop holistic individuals because it focuses on one aspect of education only either traditional Islamic education system or secular education system (Crystal et al., 2011 p.24). On one side, education focuses on academic education, science and technology while on the other side it tends to emphasize religious education. Consequently, the generation who mastered in academic, science and technology was born but they had less understanding on religious knowledge. Meanwhile, another group had strong religious understanding but lacked in academic, science and technology. Therefore, it is clear that dualism in education causes no integration and creates imbalance to the roles of developing the country (Retrieved from http://www.sinarharian.com.my/kolumnis/cikgu-sidekbaba/dualisme-dalam-pendidikan-1.512200)

Integration of knowledge has created Islamic scholars such as Ibn Nafis who are proficient in Arabic and Syar'iyyah knowledge as well as having specialties in medical science specializing in haematology. In addition, there are other great names such as Ibn Sina, Al-Razi, Al-Biruni, Ibn Al-Haitham, al-Kindi and many more from all over the world. The secular science methodologies such as experiments, findings and observations used by these Islamic scholars was learnt from other civilizations (mostly Greek philosopher) that eventually resulted in creative and innovative inventions. From that, came a great scientific civilization and the western owed the knowledge from the Islamic civilization (Sidek Baba, 2009, p.47). In the golden age of Islam, science and technology developed in harmony with Islamic teachings themselves led by the leadership of a credible Muslim community to perform their duty as the caliph of Allah (Mohd Yusof, 2010, p.2). Based on that, Islamic teachings are essentially the ones that have generated the development of science and technology. Hence, science and technology cannot be separated from knowledge related to divinity, morality, and ethics. Thus, it is argued that the confusion will be overcomed and the role of knowledge and education in restoring adab and faith in God will be restored with the proper inculcation of the Islamic world view (al-Attas, 1978 and 1980).

Therefore, the goal of this study is to examine the perception of students at Tamhidi Centre of Universiti Sains Islam Malaysia (USIM) on the implementation of Naqli and Aqli elements in the teaching and learning of chemistry course. Naqli elements mentioned in this study refers to the knowledge of the revelation which are al-Quran and hadith while Aqli elements is the knowledge of science named chemistry.

\section{METHODOLOGY}

This study employed a quantitative methodology using questionnaire approach that aims to survey the opinions of students about the elements of Naqli and Aqli presented in the teaching and learning of chemistry course. A formal standardized questionnaire is used as survey instrument to collect data from 106 respondents consisting of 51 male students and 55 female students from Tamhidi Centre of USIM. The questionnaires were handed out to the three Tamhidi groups; Medicine, Dentistry and Science and Technology with ratio of 25,15 and 16 respectively.

The questions are closed (or multiple choice) questions that require the respondents to choose among several answer categories using a frequency scale. The respondents need to answer ten items related to their perception towards teaching and learning of chemistry course based on five-point Likert scale which are; Strongly Disagree (1), Disagree (2), Not Sure (3), Agree (4) and Strongly Agree (5). Then, the answers will be analyzed to obtain the mean score and significant difference in order to identify the final perception. 


\section{CONCEPT OF NAQLI AND AQLI}

Teaching and learning exist since the creation of prophet Adam (as). He was treated differently from the other creatures as The Almighty Allah has created him for specific reasons (Al-Migdadi, 2011, p.4). Adam had the ability to learn and teach as Allah says:

"And He (Allah) taught Adam all the names (of everything), then He showed them to the angels and said: «Tell Me the names of these if you are truthful. They (angels) said: Glory be to You, we have no knowledge except what You have taught us. Verily, it is You, the All-Knower, the AllWise" (al-Baqarah: 31- 32).

Based on this verse, it can be said that knowledge and education cannot be separated from religion. AlQuran is the first guidance from Allah and followed by sunnah. Allah has granted two sources to man in order to achieve two types of knowledge including the knowledge through revelation and prophet as well as the acquired knowledge learned through experiences and when man strives with his mind (Al-Migdadi, 2011, p.5). However, in this context of sciences knowledge nowadays were bound to clash with Islamic values and guidelines as it tends to reflect the West's values, concepts, and beliefs, upon which all Western aspects of behaviour, activity, and social institutions were established. The Muslim scholars and intellectuals have to fulfill the western needs not realizing that the sciences have been established in accordance to the west ideology and vision (Hamidullah, 2016, p.60).

According to al-Faruqi, that was the basic cause of the malaise of the Ummah. Hence, al-Faruqi came with an idea to reformulate all new branches of knowledge based on the worldview of Islam. Al-Faruqi asserted that the disciplines, the humanities, the social sciences and the natural sciences must be reconceived and rebuilt, given a new Islamic base and assigned new purposes consistent with Islam. Every discipline must be recast so as to embody the principles of Islam in its methodology, in its strategy, in what it regards as its data, its problems, its objectives, its aspirations. Every discipline must be remolded so as to incorporate the relevance of Islam, a long a triple axis constitutive of tawhid (Al Faruqi, Islamization, 1982, x).

Since the modern western education system is introduced in the Muslim world, al-Faruqi said that the Muslim ummah has lost the true dynamic spirit of the past madrasah education. Therefore, Islamic vision and an original approach for methodology of knowledge should be emphasized, incorporating the three Islamic sources of knowledge: revelation (wahy), reason (aq), and the universe (al-kawn) (Hamidullah, 2016, p.60). Thus, Muslims should realize the need of Islamization of Knowledge in education to avoid the annihilation of Islamic values. USIM advocates similar concept with the objective to eliminate the gap between Islamic knowledge and worldly knowledge through its promotion of the integration of Naqli and Aqli. USIM adopted the approach of both disciplines to meet the physical and spiritual needs (Ibrahim et al., 2015, p.491).

Naqli or revealed knowledge refers to a knowledge that came from authentic sources such as Al-Quran and the Sunnah of Prophet Muhammad (pbuh). Meanwhile, the term Aqli or non-revealed knowledge means logical and intellectual interpretation of any given matter. It also known as worldly knowledge (Siti Salmiah et al., 2016, p.3). The philosophy of USIM is to integrate both knowledge of Naqli and Aqli, as well as good character is the main platform to form excellent generation and knowledgeable society (KUIM Prospectus, 1993, p. 3). Furthermore, the mission of USIM is to be an advanced Islamic-based educational institution and to become the forefront in using the latest technology to produce innovations that can transform the nation, ummah and mankind (Ibrahim, et al, 2015).

As it is the twin concept with Islamization of knowledge, it also refers to the infusion of key Islamic elements and concepts into the new or foreign elements and concepts. According to Al-Attas, several keys of Islamic elements and concepts are that of religion (din), man (insan), knowledge (ilm and marifah), wisdom (hikmah), justice (adl), right action (amal as adab). All of them are linked to the concept of God, His Essence and Attributes (tawhid); the meaning and message of the Holy Qur'an, the Sunnah and the Shariah (Daud, 1991, p. 37). Mohd Kamal Hasan (1993) in his paper has stated the need for an integrated education system that integrates the religious and worldly knowledge so that the personalities born from that kind of education system not only have mental intelligence and Islamic perspective but also have nobility, noble souls and good characters.

\section{TAMHIDI CENTRE OF UNIVERSITI SAINS ISLAM MALAYSIA}

The Tamhidi (Foundation) Centre is a preparation program for the pre-university level known as the term 'Matriculation' at the Ministry of Education Malaysia and International Islamic University of Malaysia, 'Foundation' at the University of Malaya or similar to the pre-university program (STPM, HSC Or A 'Level) (Retrieved from http://tamhidi.usim.edu.my/info-usim). 'Tamhidi' is USIM's "branding" which uses Arabic 
language as a medium. Tamhidi Centre was set up as a feeder program that started its operations beginning academic session $2004 / 2005$. This program aims to increase pre-university opportunities in particular to 'bumiputera' Muslim from science stream background in religious schools in line with the USIM academic development plan (Aziz et al, 2016).

Tamhidi Centre offers five programmes, namely Tamhidi of Medicine, Tamhidi of Science and Technology, Tamhidi of Dentistry, Tamhidi of Accounting and Muamalat, and Tamhidi of Shari'ah and Law. These programmes are offered for SPM graduates. Meanwhile, the duration of study for Tamhidi program is one (1) year and it is divided into two (2) semesters. A final exam will be held for each subject in every semester. In addition, each subject will also undergo continuous assessment through quizzes, assignments, presentations, mid-semester exam and others that will be determined by the related instructors (Tamhidi Centre, 2017, 36).

Tamhidi Centre is targeted to assist an increase in the number of students to the bachelor degree programmes at USIM. However, students must pass all courses with a minimum CGPA of 2.00 before eligible for consideration to the first degree studies related. USIM aims to produce Muslim professionals with expertise in the fields of Medical Sciences, Science, Technology, Engineering, Economics, Accounting, Muamalat, Syariah and Law (Retrieved from http://tamhidi.usim.edu.my/info-usim). As Naqli and Aqli knowledge are also introduced to Tamhidi students in their subjects, they are prepared with Naqli and Aqli knowledge during Tamhidi level and will be proficient in their course. At the same time, they are going to have good characters, discipline, and responsible for the religion, society, and nation in line with the integration of Naqli and Aqli knowledge.

\subsection{Tamhidi of Dentistry, Tamhidi of Medicine and Tamhidi of Science and Technology}

Tamhidi of Dentistry, Tamhidi of Medicine and Tamhidi of Science and Technology were set up to produce high-skilled students from science stream background and are highly capable to be enrolled into degree programs especially in Faculty of Medicine and Health Sciences, Faculty Science and Technology and Faculty of Dentistry. Some of the courses that can be selected are medicine and surgery, food biotechnology, actuarial science and risk management, security and information assurance, financial mathematics and dental surgery (Ibrahim, 2016).

The structure of curriculum for Tamhidi of Dentistry, Tamhidi of Medicine and Tamhidi of Science and Technology is designed to ensure that the objective of the programme is achieved through the components in which all students are required to take and pass all the subjects. Among the general components are Quranic and Hadith Studies in Science and ICT Skills. The language component includes Arabic language and English language while the programme components are Biology, Physics, Chemistry and Mathematics (Tamhidi Centre, 2017, p. 45). However, in this study, the researcher will just focus on the teaching and learning of chemistry course.

Based on the course structure, students are required to take chemistry course as it is included in the programme component. For the first semester, they have to pass Chemistry I subject which hold four credit hours while in semester two, they have to complete Chemistry II subject with the same credit hour. Chemistry I aims to provide students with a comprehensively understanding of the general principles and methodologies of chemistry. It covers topics on physical and inorganic chemistry, such as atoms, molecules and ions, stoichiometry, atomic and electronic structure, periodic properties of elements, chemical bonding, molecular geometry, gaseous, liquid and solid state as well as chemical kinetics. Other topics include properties of solution, chemical equilibria and acid-base equilibria. The laboratory component is a complementary for materials discussed in this subject (Ibrahim, 2016).

In Chemistry II subject, students are expected to be able to explain and apply the basic concepts, principles and theories of fundamental chemistry. They should also be able to conduct simple experiments, as well as to interpret data and present physical and chemical properties of organic compounds. Some topics that have to be completed in this course such as physical chemistry and it is a basic introduction organic chemistry. Physical chemistry will discuss topics on thermochemistry, electrochemistry and reaction kinetics. An introduction to organic chemistry will be covered on bonding and structural formula including basic properties, preparation and reaction of various classes of organic compounds. It will include hydrocarbon, haloalkanes, hydroxyl compounds, carbonyl compounds, carboxylic acid and derivatives and amines. Other topics include amino acids, proteins, carbohydrates and polymers (Tamhidi Centre, 2017, p. 60). In this study, the integration of Naqli and Aqli in the chemistry course will be discussed. 


\section{FINDINGS}

Figure 1 relates to the extent of students' knowledge about the science of chemistry in al-Qur'an. One respondent $(0.94 \%)$ strongly disagree to this item while no one is disagree and six respondents $(5.66 \%)$ were not sure. Meanwhile, the number agreeing to this item is significantly higher that is 44 respondents $(41.51 \%)$ and the highest is the number of strongly agree which is 55 respondents (51.89\%). The average value of this item is 4.43 .

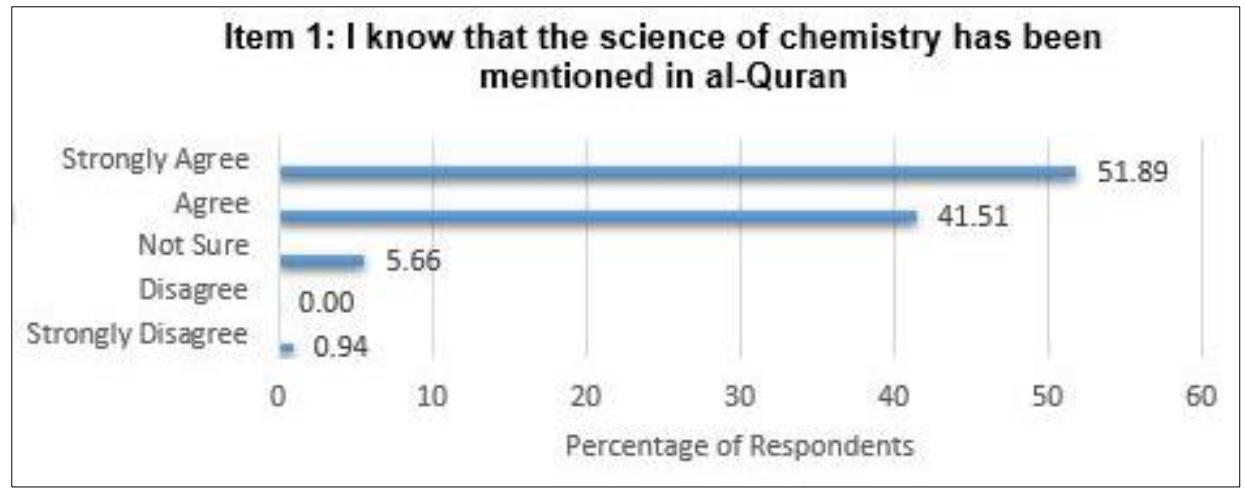

Figure 1: Respondents' perceptions toward item 1

The questionnaire was also carried out to see whether the respondents understood and therefore become more interested in learning chemistry through the integration of Naqli and Aqli. Figure 2 shows the number of respondents who are strongly disagree and disagree to this item is only one respondent $(0.94 \%)$ each. Six respondents were not sure while 55 respondents (51.89\%) agreed and 43 respondents $(40.57 \%)$ were strongly agree to this item. The study of Naqli and Aqli in fact makes them become fascinated with the creation of Allah since they can imagine and understand the properties of the smallest structure of subatomic particles. The average value of this item is 4.30 .

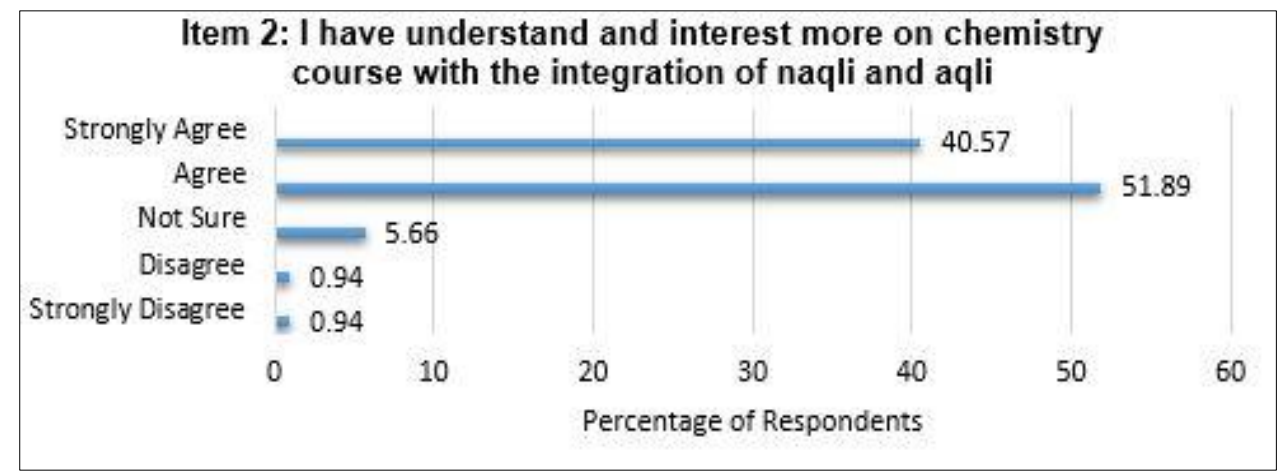

Figure 2: Respondents' perceptions toward item 2

Based on Figure 3, no one is strongly disagreed and only two respondents $(1.89 \%)$ disagreed that they gain more confidence in study with the integration of Naqli and Aqli. Ten respondents $(9.43 \%)$ were not sure about the statement while 38 respondents $(35.85 \%)$ agreed that they gained more confidence. A majority of respondents (56) reported that they strongly agreed with item 3 . The average value of this item is 4.39 . 


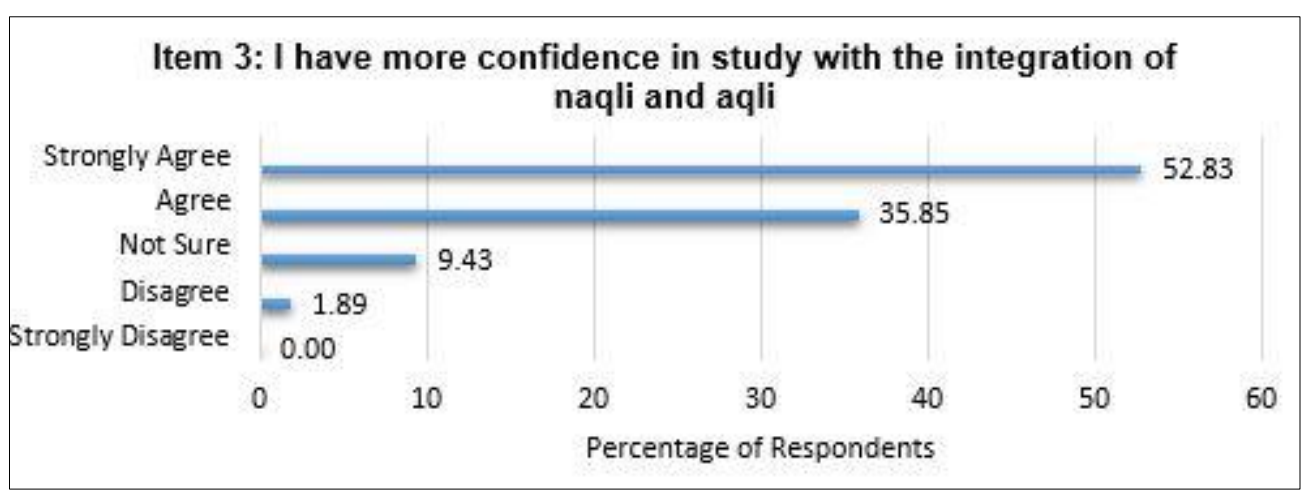

Figure 3: Respondents' perceptions toward item 3

Only one respondent $(0.94 \%)$ strongly disagreed and disagree that the integration of Naqli and Aqli enable them to link the chemistry concept with al-Quran and hadith. From Figure 4, it demonstrates that four respondents were not sure about item 4 . About 43 respondents $(41.35 \%)$ agreed while 58 respondents $(55.77 \%)$ strongly agreed that they can understand the chemistry concept linked to the verses of al-Quran. The total mean value for this item is the highest which is 4.50 .

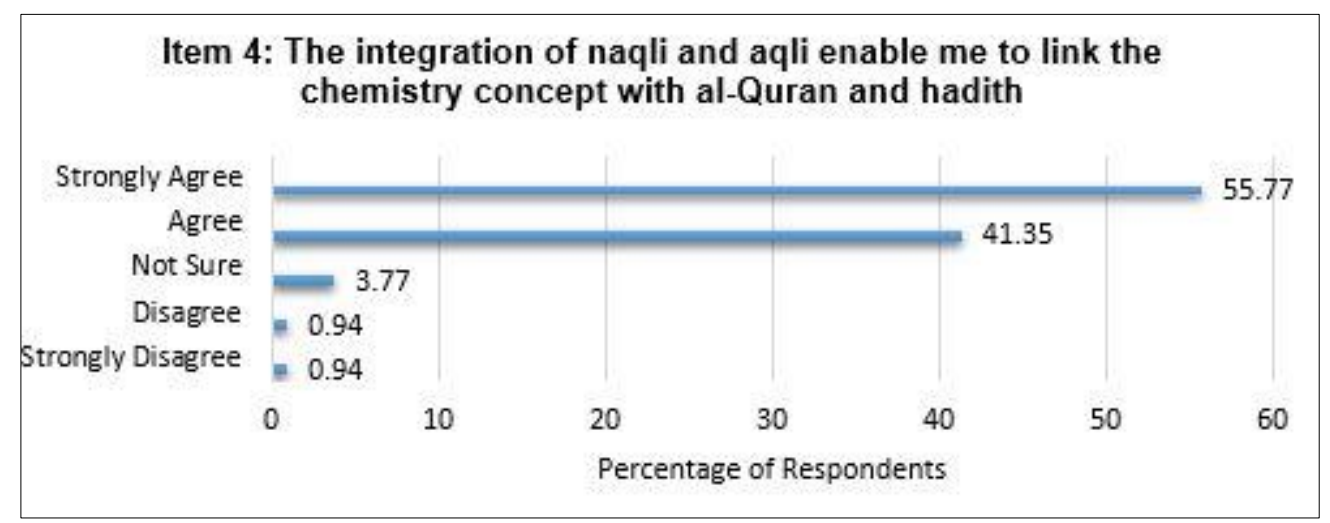

Figure 4: Respondents' perceptions toward item 4

Following Figure 5, respondents have been asked whether the teachers in chemistry subject were able to create an interesting learning environment through the integration of Naqli and Aqli. Two respondents $(1.89 \%)$ strongly disagreed, and no one tends to disagree. Ten of whom said they are uncertain with this statement. 45 respondents (42.45\%) said they agreed and 49 respondents $(46.23 \%)$ gave a very agreeable answer. The average value of this item is 4.31 .

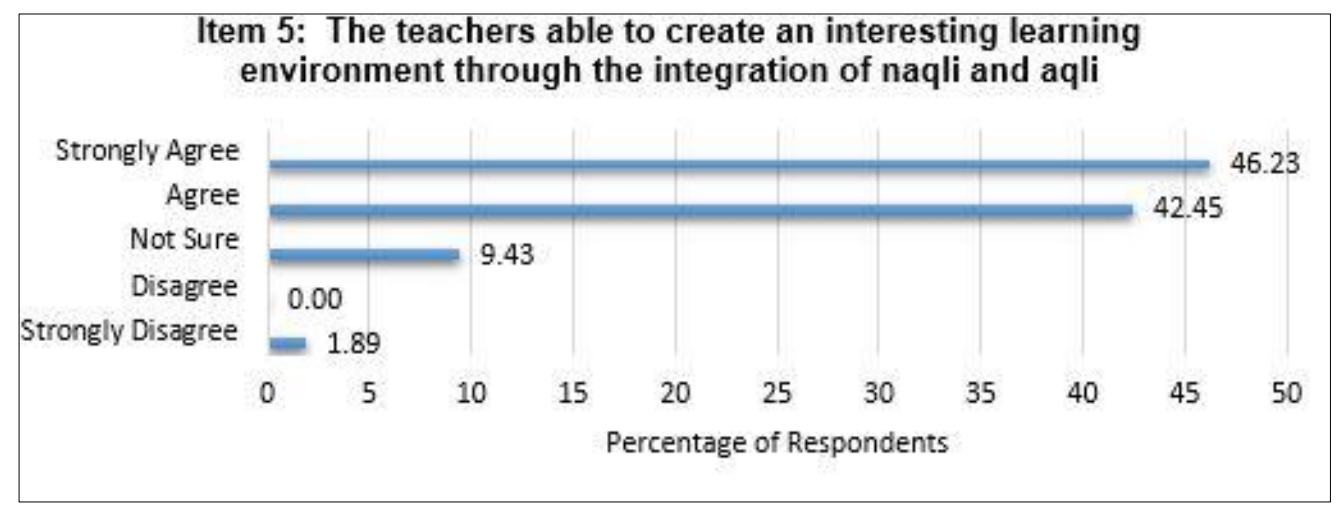

Figure 5: Respondents' perceptions toward item 5

The survey in Figure 6 shows that nobody chose strongly disagree to the statement that the textbook used in Naqli and Aqli integration is worthy to start exploring new knowledge. Only two respondents $(1.89 \%)$ agreed while seven respondents $(6.60 \%)$ said that they were not sure about that. Almost half of 106 respondents 
$(49.06 \%)$ agreed and the total of strongly agree is slightly lower than those who agreed which is 45 respondents (42.45\%). To sum up, the mean value of this item is 4.32 .

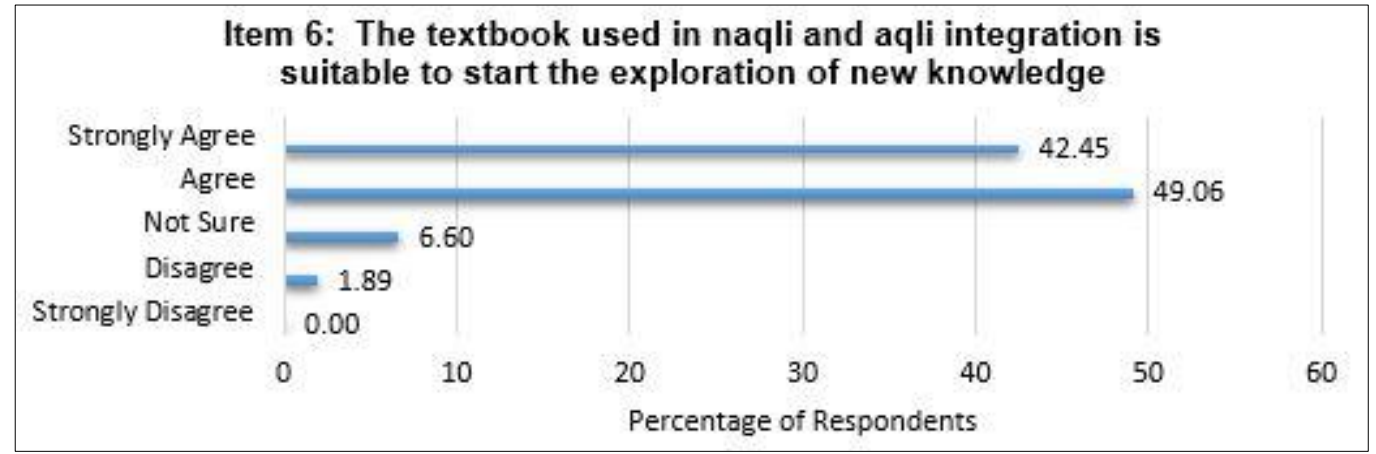

Figure 6: Respondents' perceptions toward item 6

When asked if the teachers explained Naqli and Aqli clearly and appropriately, two respondents indicated that they strongly disagreed with that while a respondent disagreed. Based on Figure 7, 17 respondents $(16.04 \%)$ were uncertain while the number of agree and strongly agree are totally the same that is 43 respondents $(40.57 \%)$. The average value for this item is the lowest which is 4.16 .

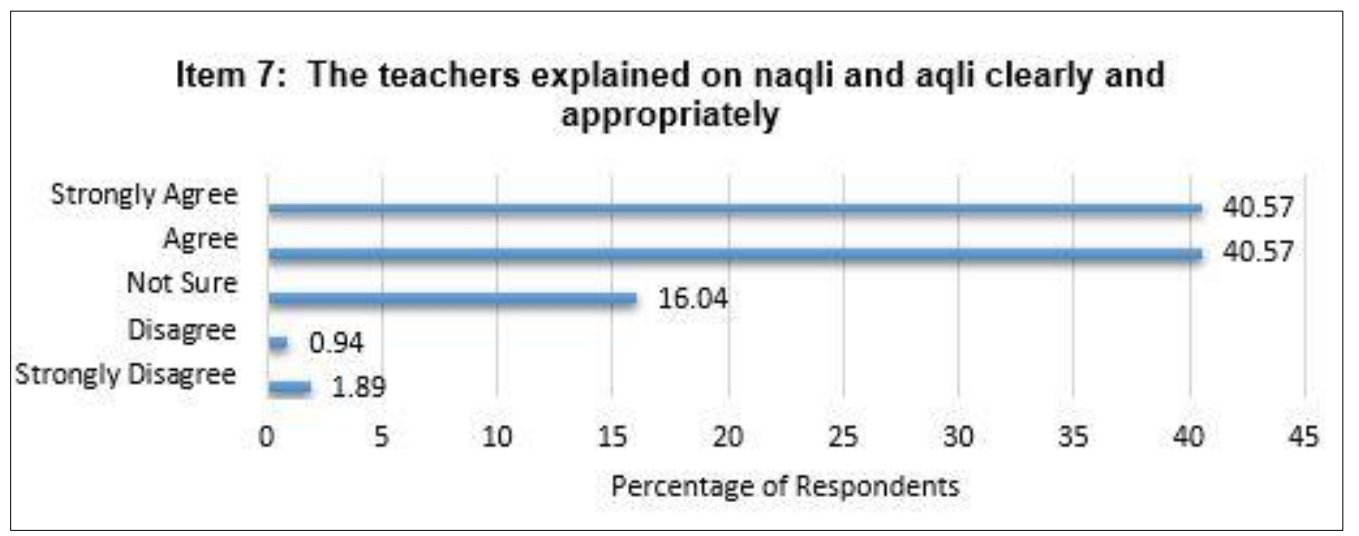

Figure 7: Respondents' perceptions toward item 7

A majority of respondents (45.28\%) reported they agreed that the teachers have cultivated the integration of Naqli and Aqli in chemistry subject. There is less about two respondents $(43.40 \%)$ who strongly agreed. Figure 8 also indicates that nine respondents (8.49\%) were uncertain and two respondents $(1.89 \%)$ disagreed. Meanwhile, there is just one respondent $(0.94 \%)$ strongly disagreed to the statement. The mean value is 4.28 .

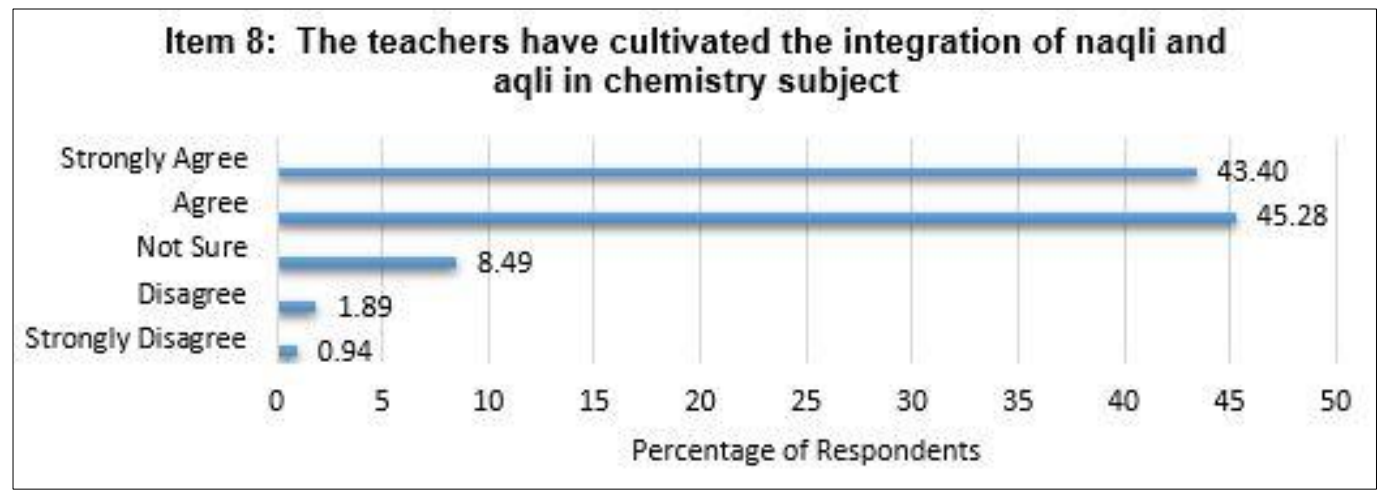

Figure 8: Respondents' perceptions toward item 8

Responses to the question about whether they have interest to know more about the Islamic scholars such as Ibnu Sina and al-Khawarizmi by the existence of Naqli and Aqli integration in Figure 9 revealed that most 
of respondents strongly agreed (50\%) to that statement. 47 respondents (44.34\%) agreed while five respondents $(4.72 \%)$ were not sure about their opinion. No respondent disagree but one respondent strongly disagreed to that, came out with a quite high of total average which is 4.42 .

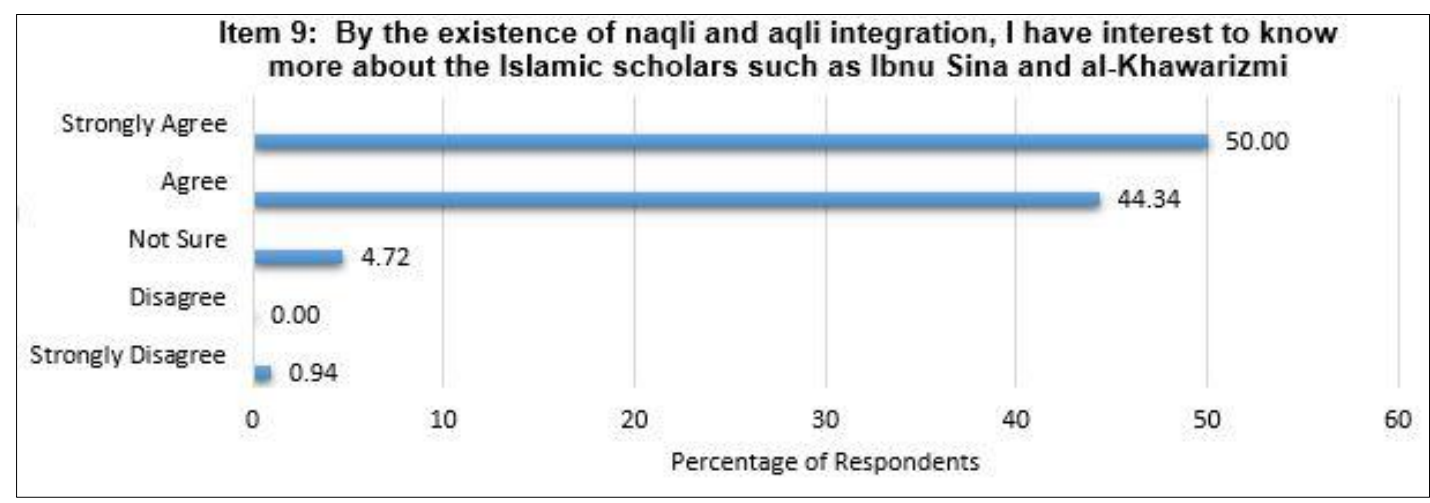

Figure 9: Respondents' perceptions toward item 9

Regarding Figure 10, more than half (51.89\%) respondents agreed that the knowledge of Naqli and Aqli mentioned in teaching and learning of chemistry subject is just a small part from al-Quran and hadith. About 42 respondents $(39.62 \%)$ respondents strongly agree while six respondents have no stand about this statement. There is no respondents agree but three respondents $(2.83 \%)$ strongly disagreed. Thus, the mean value is 4.25 .

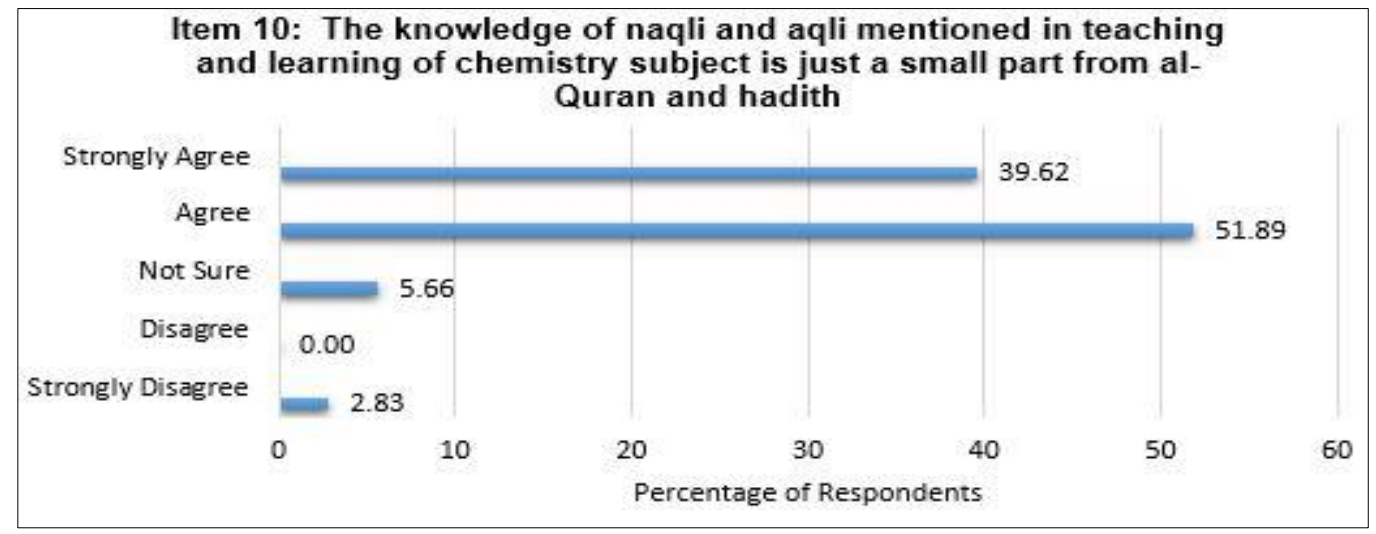

Figure 10: Respondents' perceptions toward item 10

\section{DISCUSSIONS}

In this discussion, the fundamental goal drove the collection of data and the subsequent data analysis. The goal was to discover the students' perceptions toward the integration of Naqli and Aqli in the teaching and learning of chemistry course at Tamhidi Centre in USIM. Based on the above analysis, the results of each item shows that the majority of respondents from 106 Tamhidi students chose "strongly agree" and "agree". Both selections have gave positive feedback on the perception of the course. The students might chose these two answers because they were from Islamic-based background which is from religious school as well as they understood the importance of the combination of Naqli and Aqli knowledge generally.

Referring to the findings above, it is discovered that the highest average value is on item number four (4.50). Most students selected option 'strongly agree' for this item. They asserted that the integration of Naqli and Aqli knowledge has enabled them to associate the concept of chemistry with al-Quran and hadith. This result indicated that the integration has brought success in term of producing Quranic generation. Sulaiman (2010) stated that one of the methods to know Allah SWT as the creator of all nature is through scientific research and thoughts of the natural world. The integration of knowledge consequently lead to tafakkur on oneself and thinking deeply as well as critically. As Allah said in al-Quran: "And He has subjected for you the night and day and the sun and moon, and the stars are subjected by His command. Indeed in that are signs for a people who reason" (Al-Nahl: 12). This result can be concluded as a very positive result as the Quranic 
generation built from the people who made al-Qur'an as the main source and a basis for thoughts in order to success in this world and hereafter.

It is also found that the result of item seven gave the lowest average since the mean is only 4.16. Research concluded that the students are confused about the teaching methods in delivering Naqli and Aqli knowledge. Thus, the findings suggest that the teachers should continually be exposed and trained with the suitable methods in teaching chemistry combined with Naqli and Aqli knowledge. Appropriate methods and techniques tend to create an interesting environment for learning. In the process of integration of knowledge, it is important for an educator to master the knowledge of Naqli and Aqli. This is to help the implementation of the integration process goes smoothly as well as current pedagogy which is very important for an educator. The teacher also acts as a facilitator who is closest to the students (Zetty et al., 2017, p.165). Thus, it is concluded that the role of a teacher is not just about teaching the subjects of the school, but also as a mentor who acts to educate the mind and build on the morality of students to become a good and quality society member.

\section{CONCLUSIONS}

To summarize, the most fundamental thing in teaching and learning is the achievements of learning outcomes. Teaching and learning in chemistry course should use whatever approaches and methods that are clear and appropriate so that the students can easily understand chemistry course through Naqli and Aqli integration as well as getting to focus on developing the physical and spiritual aspect to complement the growth of the human potential that is balanced and comprehensive. It is also important to make sure that the students are able to get the message through the holistic approach of Naqli and Aqli in teaching and learning process. The education system in Malaysia should lead this concept so that the generation formed later is a Muslim generation who has developed from the diverse aspects of science that does not separate the knowledge of Naqli and Aqli. Overall, the analysis of the students 'perceptions on chemistry course have received positive responses from Tamhidi students and this study is hoped to give benefits to the university and Tamhidi Centre particularly.

\section{ACKNOWLEDGEMENT}

Sincere gratitude and appreciation to Research Management Centre Universiti Sains Islam Malaysia (USIM) for the management. The researchers would like to acknowledge Miss Siti Zulaikha Mokhtar for the article editing. This research is supported by the research grant (PPP/USG-0215/TAMHIDI/30/17215) and (PPP/USG-0115/FPQS/30/11415).

\section{REFERENCE LIST}

Al-Attas, S. M. N. (1978). Islam and Secularism. Kuala Lumpur: ABIM.

Al-Attas, S. M. N. (1980). The Concept of Education in Islam: A Framework of an Islamic Philosophy of Education. Kuala Lumpur: ABIM.

Al-Faruqi, Ismail Raji. (1982). Islamization of knowledge: General principles and workplan. London: International Institute of Islamic Thought.

Al-Migdadi, Mahmoud Hamid. (2011). Issues in Islamization of Knowledge, Man and Education. Revue Académique des sciences humaines et sociales. Al al-Bayt University.

Aziz, AA., Ibrahim, MA, Shaker, MH \& Nor, AM (2016). Teaching Technique of Islamic Studies in Higher Learning Institutions for Non-Arabic Speakers: Experience of Faculty of Quranic and Sunnah Studies and Tamhidi Centre, Universiti Sains Islam Malaysia. Universal Journal of Educational Research 4(4): 755 760. DOI: 10.13189/ujer.2016.040412. Horizon Research Publishing, USA.

Crystal Joan Peter, Rohana Hamzah \& Amirmudin Udin. (2011). The Impact Of Dualism In Education On Sustainable Development Through TVET. Journal of Edupres. 1 Johor: Universiti Teknologi Malaysia.

Daud, Wan Mohd. Nor Wan. (1991). The Beacon on the Crest of a Hill-A Brief History and Philosophy of the International Institute of Islamic Thought and Civilization [ISTAC]. ISTAC, Kuala Lumpur, Malaysia. 
IJASOS- International E-Journal of Advances in Social Sciences, Vol. III, Issue 9, December 2017

Hamidullah Marazi. (2015). Empowering Education with Values and Integration of Religion And Science: Madrasah Al-Zahra Model. Proceedings of ICIC2015 - International Conference on Empowering Islamic Civilization in the 21st Century. Universiti Sultan Zainal Abidin, Malaysia.

Ibrahim, MA., Yusoff, AM., Aziz, AA., \& Nor, AM., (2015). Integration of Naqli and Aqli Knowledge In Education Curriculum: Experience Of Faculty Of Quranic And Sunah Studies, Universiti Sains Islam Malaysia. Proceedings of INTCESS15- 2nd International Conference on Education and Social Sciences. Istanbul, Turkey.

Ibrahim, MA., Tamjid, MM. \& Yaman, MNM., (2015). 11 Tahun Tamhidi Menerajui Kurikulum Berteraskan Integrasi IImu Naqli \& Aqli: Tinjauan Terhadap Enrolmen Pelajar. Proceeding of Konvensyen Sains Islam 2015 (KONGSI'15). USIM: Nilai.

Ibrahim, MA, (2016). The Integration of Naqli Knowledge of Science Courses in Institutions of Higher Learning Foundation Centres: Study on Tamhidi Centre, Universiti Sains Islam Malaysia. Proceedings of ADVED 2016 2nd International Conference on Advances in Education and Social Sciences. Istanbul, Turkey.10-12 October 2016- Istanbul, Turkey.

KUIM Prospectus. (1993). Kuala Lumpur: Kolej Universiti Islam Malaysia.

Ministry of Education Malaysia. (n.d) Retrieved August 18, 2017:

http://www.moe.gov.my/index.php/en/dasar/falsafah-pendidikan-kebangsaan

Mohd Yusof Othman. (2010). Al-Quran dan Sains (Nuklear). Presented at the Penang State Level Al Quran Seminar 1431H / 2010M, organized by the Penang State Government at the Millennium Hall, Kepala Batas on 18 July 2010. Universiti Kebangsaan Malaysia.

Shafeeq Hussain Vazhathodi Al-Hudawi, Mohammed Borhandden Musah \& Rosy Lai Su Fong, (2014). Malaysian National Philosophy of Education Scale: PCA and CFA Approaches. Asian Social Science, 10 (18). http://dx.doi.org/10.5539/ass.v10n18p16.

Sidek Baba. (2009). Acuan Minda. Shah Alam: Alaf 21 Sdn Bhd

Sidek Baba. (2016). Retrieved August 16, 2017: http://www.sinarharian.com.my/kolumnis/cikgu-sidekbaba/dualisme-dalam-pendidikan-1.512200

Siti Salmiah Muhammad, Emelia Effendy \& Mohd Muzhafar Idrus. (2016). A Preliminary Study on The Integration of Naqli and Aqli Knowledge: USIM Experience In English For Professionals Course. Proceeding iECNA 2016 (23-24 August 2016). USIM: Nilai.

Sulaiman Nordin.(2013).Sejarah Pemikiran 2.Bangi.Universiti Kebangsaan Malaysia.

Tamhidi Centre. (2017). E-Panduan Program Tamhidi Sesi Akademik 2017/2018. Universiti Sains Islam Malaysia.

Tamhidi Centre. Universiti Sains Islam Malaysia. http://tamhidi.usim.edu.my/info-usim

Zetty Nurzuliana Rashed, Siti Rashidah Abd. Razak, Norshilawani Shahidan, Ahmad Shafiq Mat Razali, Zanaton H Iksan \& Sri Andayani Mahdi Yusuf. (2017). Strategi Pengajaran Guru Pendidikan Islam Mengintegrasikan IImu Naqli dan Aqli Menggunakan Pendekatan 'Lesson Study'. Jurnal Sultan Alauddin Sulaiman Shah. 4(1). 